\title{
Positive psychological correlates of career competency among panchayat school students
}

\author{
Ramasamy R ${ }^{1, *}$, Nithyanandan D..$^{2}$ \\ ${ }^{1}$ Research Scholar, ${ }^{2}$ Assistant Professor, Dept. of Psychology, Periyar University, Salem, Tamil Nadu, India \\ *Corresponding Author: \\ Email: rajaramasamy13@gmail.com
}

\begin{abstract}
Aim: The present study aims to explore the psychological correlates that are related to career oriented positive psychological strengths, namely, Career Adaptability, Career Optimism and Perceived Knowledge among the panchayat school students.

Materials and Methods: It is basically a report of the pilot study for a major ICSSR fellowship study which is exploratory and descriptive in nature. A popular village panchayat school in Salem district with a 300 students was chosen as the target school. 134 students were randomly selected. Of them 80 were girls and 54 were boys. They were all administered career futures inventory developed by Patrick Joseph Rottinghaus (2004). It measures career optimism, career adaptability capacities and perceived knowledge. In this study these variables are considered positive psychological variables for positive psychology has emerged as a separate branch of study and the field has started attracting controlled randomized experimental investigations.

Synopsis of the Result: The percentage analysis revealed that $70.1 \%$ of students have chosen a career and have not investigated about their chosen career. $21.6 \%$ of students investigated a number of careers and have selected only one. $47.8 \%$ of the students quite often think about their career goals. $40.3 \%$ of students said they put high level of effort for their school work. $66.4 \%$ of students said they put high level of effort for learning about their career options. During a typical week, only $2.2 \%$ of students spent over 60 hours of activities related to their school work. $4.5 \%$ of students are found to be very dissatisfied about their current major. $41 \%$ of students are spending 16-30 hours and $6 \%$ are over 60 hours to explore their career options during the last 6 months. The analysis of correlation revealed no significant relationship among these three variables. However, results of independent t' test revealed that Female village panchayat school students were found to have more career adaptability capacities and perceived knowledge. It was also revealed that $11^{\text {th }}$ Std. students are found to have more career adaptability and perceived knowledge than the $12^{\text {th }}$ Std. students.

Implications: Students in the city have many career related advices and advantages but in the rural area, for the Panchayat School students their career development is not systematic. Hence, the main study focuses on enhancing these through a systematic positive psychological intervention. The implications are discussed in the main article in line with the contemporary career psychological perspectives.
\end{abstract}

Keywords: Optimism, Adaptability, Perceived Knowledge, Career Features, Panchayat, Village Students.

\section{Introduction}

In today's world, students are facing extremely tough challenges in the form of career development. This research article, based on a solution focused study, applies the science of positive psychology. The rationale behind the study is that by improving positive psychological variables namely, adaptability and optimism along with the perceived knowledge among school students about the future or the success their career efforts can be systematically positively developed. According to Parsons $(1909,5)$, the father of vocational guidance who wrote the classical book "Choosing a vocation", "there are three broad factors: ${ }^{1} \mathrm{a}$ clear understanding of oneself, one's aptitudes, abilities, interests, ambitions, resources, limitations, and their causes; ${ }^{2}$ a knowledge of the requirements, conditions of success, advantages and disadvantages, compensation, opportunities and prospects in different lines of work $;^{3}$ true reasoning on the relations of these two groups of facts.' These are considered to be the elements of career development and to have sustained efforts on these during the adverse conditions the positive career psychological aspects come in help. In this study these aspects are explored among the rural, economically and socially backward school students (predominantly Dalits).

Career Adaptability (CA): Career Adaptability is considered a psychosocial construct that denote individuals' potential to deal with current and anticipated developmental tasks, occupational transitions, and work trauma (Savickas, 1984). In the modern era change in career life is very dynamic. It runs along with the changes in technology like the emergence of multinational life styles in the local area. The individual is required to understand different work cultural habits, for instance, preparing resume for a multinational company is different from the local traditional company. To survive in the multicultural environment the individual needs to adapt different work settings. According to Super and Knasel (1981) it is a key competency in career success. They view the construct to be free of any age or stage of life effect, which increases its applicability across ages and includes the interaction of environment. Instead of focusing on growth or maturity they further emphasize on looking forward according the needs of the environment. Rottinghaus et al. (2005) opines CA as a 
predisposition that impacts the way individuals perceive their capacity to map and regulate to changing career plans, especially in the face of unexpected circumstances. All of these definitions highlight the significance of the interface between individuals and their environment and lay emphasis on supervision of problems that confront them.

Career Optimism (CO): Rottinghaus et al. (2005) considers $\mathrm{CO}$ as a predisposition to expect the most promising outcome or to lay emphasis on the most affirmative features of one's future career development, and comfort in performing career planning tasks. Career Optimism is a sparsely researched topic. Four studies focusing on Career Optimism require special mention here - one by Friedman et al. (1998), and others by Hennesseya et al. (2008), Gunkel et al. (2010) and Duffy (2011). In the first two studies, Career Optimism was defined as an individuals' confidence regarding their capability to decide, preserve, and go forward in an appropriate career. Studies by Gunkel et al. (2010) and Duffy (2011) used Rottinghaus et al. (2005) definition to understand Career Optimism.

Perceived Knowledge (PJK): Rottinghaus et al. (2005) coined the term Perceived Knowledge of Job Market (henceforth referred to as PJK) which measures perceptions of how effectively an individual comprehends job market, and employment trends and patterns. People explore job market and employment trends in order to foster progress in their career development. Getting adequate information about job market is especially relevant in the context of times of transition and unexpected events and allows individuals to adjust to a set of shifting challenges (Flum \& Blustein, 2000; Hall, 1986; Taveira \& Moreno, 2003). It includes holistic environmental exploration involving exploring career options by proactively collecting information on jobs, organizations, occupations, or industries that allows more informed career decisions. Engaging in these forms of exploration may facilitate a clearer understanding of individual career ambitions including opportunities for accessing desired work contexts as well as specific work activities.

\section{Aim}

To explore the career adaptability, career optimism and perceived knowledge among students of a panchayat higher secondary school in an economically backward block which predominantly consists of Dalits.

\section{Materials and Methods Hypotheses}

Ho1: There is no relationship between career optimism, career adaptability and perceived knowledge
Ho2: There is no significant difference between male and female students with regard to career optimism, career adaptability capacities and perceived knowledge Ho3: There is no significant difference between $11^{\text {th }}$ standard and $12^{\text {th }}$ standard students with regard to career optimism, career adaptability capacities and perceived knowledge

\section{The sample}

The sample consists of 300 students from a panchayat higher secondary school. Among them 134 students were randomly selected of which 80 were girls and 54 were boys.

\section{Tools}

1. Personal Data Sheet: A personal data sheet was used to collect personal data including gender, academic standing, nature of study, type of family and some survey questions related to career choice selection (for example: Major Choice Status, How often do you think about your career goals?).

2. Career Futures Inventory: The scale was developed by Patrick Joseph Rottinghaus (2004). It measures career optimism (e.g. I get excited when I think about my career), career adaptability capacities (e.g. I am good at adapting to new work settings) and perceived knowledge (e.g. I do not understand job market trends). The response choices are: 1. Strongly Disagree, 2. Disagree, 3. Neutral, 4. Agree, 5. Strongly Agree.

\section{Method of Data Collection}

It is basically a report of pilot study for a major academic work which is descriptive and exploratory in nature. A popular village panchayat school in Salem district was selected as the target school. Primary data were collected by conducting direct group administration of the questionnaires with the consent of the head master of the school as well as the informed consent of the participants.

\section{Results}

1. Percentage Analysis: The percentage analysis revealed that $70.1 \%$ of students have chosen a career and have not investigated about their chosen career. $21.6 \%$ of students investigated a number of careers and have selected only one. $47.8 \%$ of the students quite often think about their career goals. $40.3 \%$ of students said they put high level of effort for their school work. $66.4 \%$ of students said they put high level of effort for learning about their career options. During a typical week, only $2.2 \%$ of students spent over 60 hours of activities related to their school work. $4.5 \%$ of students are found to be very dissatisfied about their current major. $41 \%$ of students are spending 16-30 hours and 6\% are over 60 hours to explore their career options during the last 6 months. 
2. Results of Correlational and Variance Analysis: The data were subjected to Karl Pearson's product correlation to understand the direction and extension of the relationship and independent sample t-test to understand whether the sample group significantly differs in terms of these three variables based on their demographic distribution. . Ho1: There is no relationship between career optimism, career adaptability and perceived knowledge

Table 1: Correlation between career optimism, career adaptability capacities and perceived knowledge

Note: NS= Not Significant

\begin{tabular}{|l|c|c|}
\hline \multicolumn{1}{|c|}{ Correlation } & Career Optimism & Career Adaptability \\
\hline Career Adaptability & .164 & 1 \\
\hline Perceived Knowledge & .002 & .120 \\
\hline
\end{tabular}

As can be seen in the table 1 the correlation coefficient among career optimism, career adaptability and perceived knowledge are not statistically significantly related in this sample. It suggests that career optimism, career adaptability and perceived knowledge are not related to each other based on the data from the present sample. However there is theoretical possibility that though they are not significantly related with each other they may independently influence the career development in each of their own way.

Ho2: There is no significant difference between male and female students with regard to career optimism, career adaptability capacities and perceived knowledge

Table 2: Career optimism, career adaptability capacities and perceived knowledge between males and females

\begin{tabular}{|l|c|c|c|}
\hline \multirow{2}{*}{\multicolumn{1}{|c|}{ Gender }} & \multicolumn{2}{|c|}{ Mean (SD) } & \multirow{2}{*}{ t-Value } \\
\cline { 2 - 3 } & Male & Female & \\
\hline Career Optimism & $38.70(3.97)$ & $38.73(3.77)$ & $0.03^{\mathrm{NS}}$ \\
\hline Career Adaptability & $37.69(4.59)$ & $40.30(4.47)$ & $3.17^{*}$ \\
\hline Perceived Knowledge & $8.83(1.61)$ & $10.66(2.33)$ & $5.0^{*}$ \\
\hline
\end{tabular}

Note: Male=N=54; Female=80; *.p<0.05; NS= Not Significant.

As shown in table 2 Panchayat School Students do not significantly differ in career optimism based on their gender. The comparison of mean score suggests that both male and female students are found to have equal career optimism. This may be because of the families' perception about the equal treatment of boy and girl children and the equal motivation from their surroundings for their career selection. Panchayat School Students significantly differ in their career adaptability at 0.05 level. Based on mean score female students are found to have more career adaptability capacity. Usually in the rural setup, especially among the economically and socially backward communities, women used to adopt various odd work roles and this may be the reason for this.

Further, table 2 reveals that Panchayat School Students significantly differ in their perceived knowledge at 0.05 level based on their gender. The comparison of mean score suggests that female students are found to have more perceived knowledge than the male students. In the rural set up the very popular profession is that of a teacher as they play a significant role in their development. Hence, many of them have sound knowledge about the teaching profession. Moreover, for female students teaching profession is an ideal job, in any Indian rural location.

Ho3: There is no significant difference between $11^{\text {th }}$ standard and $12^{\text {th }}$ standard students with regard to career optimism, career adaptability capacities and perceived knowledge.

Table 3: Career optimism, career adaptability capacities and perceived knowledge between $11^{\text {th }}$ standard and $12^{\text {th }}$ standard students

\begin{tabular}{|l|c|c|c|}
\hline \multirow{2}{*}{ Class } & \multicolumn{2}{|c|}{ Mean (SD) } & \multirow{2}{*}{ t-Value } \\
\cline { 2 - 3 } & $\mathbf{1 1}^{\text {th }}$ Std. & $\mathbf{1 2}^{\text {th }}$ Std. & \\
\hline Career Optimism & $39.00(3.88)$ & $38.53(3.88)$ & $.70^{\mathrm{NS}}$ \\
\hline $\begin{array}{l}\text { Career Adaptability } \\
\text { Capacities }\end{array}$ & $40.76(4.67)$ & $38.23(4.70)$ & $3.06^{*}$ \\
\hline Perceived Knowledge & $9.98(2.27)$ & $12.89(2.27)$ & $.23^{\mathrm{NS}}$ \\
\hline
\end{tabular}

Note: $11^{\text {th }}$ Std. $=\mathrm{N}=64 ; 12^{\text {th }}$ Std. $=70 ; *$. $<0.05 ; \mathrm{NS}=$ Not Significant

As shown in table 3 Panchayat School Students do not significantly differ in career optimism and perceived knowledge based on their class of studying.
This may be due to the fact that in almost all schools $11^{\text {th }}$ and $12^{\text {th }}$ std. students are treated alike and the 
programmes offered to them always treats them as the same.

Further, table 3 reveals that Panchayat School Students significantly differ in their career adaptability capacity at 0.05 level. The comparison of mean score suggests that $11^{\text {th }}$ standard students are found to have more career adaptability capacity than the $12^{\text {th }}$ standard students. The $11^{\text {th }}$ standard students have a capacity to adopt the different career environment. It may be contradicting to the commonsense that matured students may be more adaptive.

\section{Findings}

1. Female school students are higher in career adaptability capacities and perceived knowledge than male school students.

2. $11^{\text {th }}$ standard school students are found to have more career adaptability capacities than $12^{\text {th }}$ standard students.

\section{Conclusion}

The results of this study have to be interpreted as well as generalized after taking the following limitations into due consideration. This study depends on self-reported measures, which are susceptible to social desirability implying students may provide answers that they rather believe to be more politically correct, than indicating one's true attitudes and behaviours. Therefore, the influence of social desirability and personal perceptions must be taken into account when interpreting the results. The sample consisted of village panchayat school of Salem district in Tamilnadu only. It may not be possible to generalize the results to all educational institutions in India.

\section{References}

1. Parsons, F. (1909). Choosing a vocation. Boston: Houghton Mifflin.

2. Rottinghaus, Patrick Joseph. (2004). "Assessing career optimism and adaptability: toward the construct validation of the Career Futures Inventory

". Retrospective Theses and Dissertations.1120.

3. Flum, H., \& Blustein, D. L. (2000). Reinvigorating the study of vocational exploration: A framework for research. Journal of Vocational Behavior, 56(3),380404.

4. Hall, D. T. (1986). Dilemmas in linking succession planning to individual executive learning. Human Resource Management, 25(2),235-65.

5. Taveira, M. D. C., \& Moreno, M. L. R. (2003). Guidance theory and practice: the status of career exploration. British Journal of Guidance and Counseling, 31(2), 189-208.

6. Rottinghaus, P. J., Day, S. X., \& Borgen, F. H. (2005). The career futures inventory: A measure of careerrelated adaptability and Optimism. Journal of Career Assessment, 13(1),3-24.

7. Gunkel, M., Schlaegel, C., Langella, I. M. \& Peluchette, J. V. (2010). Personality and Career Decisiveness, An international empirical comparison of business students' career planning. Personnel Review,39,503-254.
8. Duffy, R. D. (2011). The presence of a calling and academic satisfaction: Examining potential mediators. Journal of Vocational Behavior, 79(1),74-80.

9. Hennessey, M. L., Rumrill, P. D., Fitzgerald, S., \& Roessler, R. (2008). Disadvantagement-related correlates of Career Optimism among college and university students with disabilities. Work: A Journal of Prevention, Assessment and Rehabilitation, 30(4),483-42.

10. Friedman, R., Kane, M., \& Cornfield, D. B. (1998). Social support and Career Optimism: Examining the effectiveness of network groups among black managers. Human Relations, 51(9),1155-77.

11. Super, D. E., \& Knasel, E. G. (1981). Career development in adulthood: Some theoretical problems and a possible solution. British journal of guidance and counseling, 9(2),194-201.

12. Savickas, M. L. (1985). Identity in vocational development. Journal of Vocational Behavior, 27(3),329-37. 